\title{
STRATEGY AND STRATEGIC MANAGEMENT CONCEPTS: ARE THEY RECOGNISED BY MANAGEMENT STUDENTS?
}

\section{Emerson Wagner Mainardes, João J. Ferreira, Mário L. Raposo}

\section{Introduction}

When reviewing strategic thinking, we realize how this phenomenon has gone through different phases and semantic contexts. With a millennium distancing the word from its origins, the word strategy has had several meanings but without ever losing its semantic roots. In the beginning, strategy took on a military significance and represented the action of commanding or leading armies in times of war, i.e. a military campaign [30]. It meant a way of prevailing over the adversary, a tool of victory in war and only afterwards was it applied to other contexts and fields of human relationships: political, economics, business, among others, but always retaining in all its uses the semantic root, to define paths [76].

After several phases and meanings, the concept of strategy has evolved into a field of knowledge in management, strategic management, with content, concepts and practical reasoning, ending up by carving out its own role in the academic and business fields [25]. Management uses this old military concept to associate the activities of a general with those of an organization's manager [76]. Since it represents an important tool for business management in a competitive and turbulent marketplace, the main objective of strategy involves preparing the organization to confront the current hostile environment, to this end systematically and objectively deploying the skills, qualifications and internal resources of the enterprise [25]. On the other hand, the concept of strategy still seems to be a very vague concept and subject to various interpretations [14].

An exact definition of strategy may not actually be fundamental, however, within the context of organizational knowledge management, specifically the knowledge that new professionals bring into companies, grasping which type of strategic understanding new managers bring into the organization is clearly of importance [15], [58], [74]. Thus, we may question whether concepts of strategy and strategic management are understood by business managers, especially the younger, the newly graduated in management. Therefore, this research aims to assess the acquired knowledge of university management students relating to strategy and strategic management concepts with the purpose of answering the following question: What is strategy and strategic management to future managers? Are they understood and recognized?

To answer this question, this study seeks to examine management student understanding as to the meaning of these two concepts. As specific objectives, we seek : (i) to build a model explaining the definition of strategy according to the perceptions of students graduating in management, and (ii) to identify which concept of strategic management in the existing literature comes closest to the perceptions of current management students.

To understand the perceptions of individuals about a particular concept, we adopt phenomenography type research practices. The main feature of the research method is its description of a phenomenon as it is experienced, emphasizing the collective significance of the studied phenomena, and should in no way be confused with phenomenological studies. Phenomenology is far more concerned with the individual experience of the people involved than with the phenomena studied [2].

The study is justified due to the sheer importance of the themes of strategy and 
strategic management to contemporary organizations [74]. In this sense, the survey sought to contribute towards management knowledge in the organizational environment by clarifying what is the real understanding of management graduates on the themes of strategy and strategic management.

According to Tseng [83] and Obembe [60], knowledge management in an organization begins by identifying the knowledge that individuals bring in from outside the company. In this case, the development of organizational strategy depends on understanding the perceptions of their managers on what strategy and strategic management actually is. The identification of perceptions of future managers on the two concepts, as used in this study, contributes significantly to organizational management practice. This enables the organization's management strategies as organizational knowledge on the field of strategy can hardly be managed should each manager understand the concept differently.

The study findings may also be expected to contribute to Higher Education Institutions (HEI), by identifying what level of understanding their graduating management students attain regarding the subjects under analysis. The research contribution also extends to the academic world by presenting the concepts of strategy and strategic management most present and active in the minds of future managers, findings rarely encountered in the literature. There are few studies relating strategy as a theoretical approach and its practical application in organizations [42], [68]. Thus, this study contributes to research on strategy demonstrating that the field of strategy, comprising as it does of several concepts and approaches, generates confusion among management practitioners. After all, the same phenomenon is approached in several distinctly different ways and individuals working in management would also seem to hold various perspectives, often understanding neither the real meaning of strategy nor its management [41], [62].

Furthermore, this research aims to provide some insights for lecturers bearing in mind that student opinions and knowledge on this matter reflect the efficiency and the effectiveness of the strategy related learning process [31], potentially revealing a need to change the didactics of these classes.
Another reason that led to this study was the method adopted, phenomenography, whose main characteristic is its ability to capture the perceptions of a group of people about a concept. After an exhaustive search of available scientific databases, only one study of a similar nature was found, the Shanahan and Gerber [75] research on the concept of quality in HEls, which proved the inspiration for the research set out here. Most of the other phenomenography studies found deal with educational teaching methods [5], [13], [19], [36], [63], [82] or, in fewer cases, the behaviour of consumers [88]. In the field of strategy, they both represent an innovation and a new alternative for research.

The paper is structured as follows: firstly, a literature review of the strategy and strategic management concepts from a historical perspective is carried out. Afterwards, the phenomenography research is described and explained. The methodology adopted in the survey is presented in the next section. Subsequently, the collected data are analysed and our model is tested. The article ends up with final considerations and future recommendations.

\section{Strategy and Strategic Management: a Historical Perspective}

Strategy was created by the Greeks, who endowed the concept with a military connotation. The term derives from the Greek strategos, translated as a general in command of troops or the art of the general or plan to destroy enemies through effective use of resources [18], [76], [78]. This term in itself contained the idea of objectives to be achieved and plans of action to be performed in various scenarios, depending on the enemy's behaviour [73].

According to Mintzberg and Quinn [53], strategy was already considered as an organizational skill at the time of Pericles (450 BC), meaning management skills (administrative, leadership, public speaking, power). However, it was only after World War II that strategy fully entered into the business world, which has since grown significantly and needed guidance, lines and paths to be followed by their entire structures [18]. This growth increased organizational complexity and, together with the accelerated pace of environmental changes, 
began requiring enterprises deploy greater capacity to create and manage strategies enabling them to meet the challenges of the market, reaching their objectives in the short, medium and long term [25].

According to Mintzberg [51], it was only in the 1980s that strategies underwent great development within the corporate environment. Phenomena such as corporate restructuring, joint decisions and actions impacting on organizational size, financing and portfolios [87] were driven by the technological advance in means of communication and transport and, since then, an interactive dynamic and integration on a global level have become predominant. Nowadays, thinking strategically has acquired the status of an indispensable factor in leading and managing organizations, whether for profit or otherwise [55]. After all, strategy addresses the link between the inner world of business and its external environment [68].

Considering its importance, talking about strategy opens up a discussion of theoretical approaches, ranging from the more conventional, considering strategy as a business logic, rational and sequential [21], to the most dynamic, that understand this process as associated with cultural and learning factors, politics and power relations [54]. Thus, there are two major problems affecting the understanding of what the concept of strategy really means: confusion between strategy and effectiveness tools and confusion between strategy and strategic planning [27], [56], [67]. The root of the problem seems to be the lack of a full understanding as to what strategy really is.

\subsection{Definitions of Strategy}

As can be seen, strategy is historically linked to pre-empting different scenarios and action plans to be triggered on encountering them [73]. However, there has never been a single and definite definition of strategy. The term has had several meanings, different in scale and complexity [25], [29], [35], which can mean policies, objectives, tactics, goals, programs, among others, in an attempt to express the concepts necessary for its definition [51]. However, the concept of strategy has been used indiscriminately in the field of management, meaning anything from a precisely formulated course of action, a positioning in a particular environment, through to the entire personality, the soul and existential rationale behind a company's existence. It is a concept often put forward in the academic and business worlds, filled with a great diversity and width, which in some aspects is complementary while divergent in others [68].

According to Fahey [28], there are few words subject to as many abuses in its utilisation in enterprises, as poorly defined in management literature and exposed to such different factors as strategy and hence it is a term that causes widespread discussions, especially among theorists. Mintzberg et al. [54] argue that strategy is the enemy of the deterministic and mechanistic approaches, because they minimize freedom and choice. Strategy is not only one way of dealing with an adversary in a competitive environment or market, as treated by much of the literature and its popular use [53], as it cannot only summarize the ideas, proposals, guidelines, indicative of paths and solutions [68]. Strategy instead has a breadth and scope that encircles the concept of operational efficiency [67] and cannot be confused with its tactics. In other words, strategy is not something static, finished, which renders the concept complex and difficult to grasp [25].

This fact has an explanation. Strategy in organizations, as a field of study, is much newer than its current practice [69], and its knowledge remains under construction. This can be perceived through analysis of the literature review displaying several different definitions of strategy over time (table 1).

Considering the definitions listed in Table 1, along with the hundreds more available, it would appear that the definition of what strategy means is neither closed nor simple to establish a consensus on. We cannot say any particular definition is correct. Each existing definition is correct but contains limitations in its set of assumptions and related dimensions [14].

\subsection{Definitions of Strategic Management}

According to Bhalla et al. [14], strategic management was born as a hybrid discipline, influenced by both sociology and economics. It may be considered an evolution of theories of organizations. It only began receiving more attention, from both the academic and the business worlds, in the 1950s, with its 


\section{Tab. 1: Definitions of strategy in organizational contexts (part 1)}

\begin{tabular}{l|l} 
Author(s) & Definitions of Strategy \\
\hline [10] Barnard (1938) & $\begin{array}{l}\text { Strategy is what matters for the effectiveness of the organization, the external point of view, } \\
\text { which stresses the relevance of the objectives against the environment, in terms of interna } \\
\text { stresses, the balanced communication between members of the organization and a willingness } \\
\text { to contribute towards actions and the achievement of common objectives. }\end{array}$ \\
\hline $\begin{array}{l}\text { [85] von Neumann } \\
\text { \& Morgenstern (1947) }\end{array}$ & Strategy is a series of actions undertaken by a company according to a particular situation. \\
\hline
\end{tabular}

[26] Drucker (1954) Strategy is analyzing the present situation and changing it whenever necessary. Incorporated within this is finding out what one's resources are or what they should be.

\begin{tabular}{l|l}
\hline [21] Chandler (1962) & Strategy is the determinant of the basic long-term goals of a firm, and the adoption of courses
\end{tabular} of action and the allocation of resources necessary for carrying out these goals.

[7] Ansoff (1965) $\quad$ Strategy is a rule for making decisions determined by product/market scope, growth vector, competitive advantage, and synergy.

[49] Mintzberg (1967) Strategy is the addition of the decisions taken by an organization in all aspects, as much commercial as structural, with the strategy developing in accordance with the learning process of the firm's manager.

\begin{tabular}{l|l}
\hline [20] Cannon (1968) & Strategies are the directional action decisions which are competitively required to achieve the
\end{tabular} company's purpose.

[43] Learned, Christensen, Strategy is the pattern of objectives, purposes, or goals and major policies and plans for

Andrews \& Guth (1969) achieving these goals, stated in such a way as to define what business the company is in or is to be in and the kind of company it is or is to be.

[59] Newman \& Logan (1971)

[71] Schendel \& Hatten (1972)

Strategies are forward-looking plans that anticipate change and initiate action to take advantage of opportunities that are integrated into the concepts or mission of the company.

Strategy is the basic goals and objectives of the organization, the major programs of action chosen to reach these goals and objectives, and the major pattern of resource allocation used to relate the organization to its environment.

[84] Uyterhoeven, Ackerman \& Rosenblum (1973)

Strategy provides both direction and cohesion to the enterprise and is composed of several steps: strategic profile, strategic forecast, resource audit, strategic alternatives explored, tests for consistency and, finally, strategic choice.

[1] Ackoff (1974)

Strategy is concerned with long-range objectives and ways of pursuing them that affect the system as a whole.

[61] Paine \& Naumes (1975) Strategies are macro-actions or patterns of actions for achieving the objectives of the company.

[45] McCarthy, Minichiello \& Curran (1975)

[32] Glueck (1976)

[47] Michel (1976)

[46] McNichols (1977)

[78] Steiner \&Miner (1977)
Strategy is an analysis of the environment where the organization is located and the selection of alternatives that will direct the resources and objectives of the organization, taking into consideration the risk and potential profits, and the feasibility that each alternative offers.

Strategy is a unified, comprehensive, and integrated plan designed to assure that the basic objectives of the enterprise are achieved.

Strategy is to decide which resources should be acquired and used so they can take advantage of opportunities and minimize factors that threaten the achievement of desired results.

Strategy is embedded into policy-making: it contains a series of decisions that reflect the basic objectives of the organization's business, and how to use the capabilities and internal resources to achieve these objectives.

Strategy is the formulation of missions, purposes and basic organizational goals, policies and programs to meet them, and the methods needed to ensure that strategies are implemented to achieve organizational objectives. 


\section{Tab. 1: Definitions of strategy in organizational contexts (part 2)}

\begin{tabular}{|c|c|}
\hline Author(s) & Definitions of Strategy \\
\hline [8] Ansoff (1979) & $\begin{array}{l}\text { Strategy is a set of rules for decision making under conditions of partial ignorance. Strategic } \\
\text { decisions concern the firm's relationship with its ecosystem. }\end{array}$ \\
\hline [50] Mintzberg (1979) & $\begin{array}{l}\text { Strategy is a mediating force between the organization and its environment: consistent patterns } \\
\text { in streams of organizational decisions to deal with the environment. }\end{array}$ \\
\hline [72] Schendel \&Hofer (1979) & $\begin{array}{l}\text { Strategy provides suggested directions for the organization, which allows the company to } \\
\text { achieve its objectives and to respond to opportunities and threats in the external environment. }\end{array}$ \\
\hline [18] Bracker (1980) & $\begin{array}{l}\text { Strategy has two characteristics: situational or environmental analysis that determines the } \\
\text { company's position in the market and the proper use of company resources to achieve its } \\
\text { objectives. }\end{array}$ \\
\hline [37] Hambrick (1980) & $\begin{array}{l}\text { Strategy is the pattern of decisions that guide the organization in its relationship with the } \\
\text { environment, affect the processes and internal structures, as well as influencing the } \\
\text { performance of organizations. }\end{array}$ \\
\hline [65] Porter (1980) & $\begin{array}{l}\text { Strategy is the company choice as to key decision variables such as price, promotion, quantity } \\
\text { and quality. The company, to have good performance, must be correctly positioned in its industry. }\end{array}$ \\
\hline $\begin{array}{l}\text { [52] Mintzberg \&McHugh } \\
\text { (1985) }\end{array}$ & $\begin{array}{l}\text { Strategy is a pattern in a chain of actions or decisions. It disrespects the possibilities for different } \\
\text { strategies for several environment conditions. }\end{array}$ \\
\hline [66] Porter (1985) & $\begin{array}{l}\text { Strategy is a set of offensive or defensive actions to create a defensible position in an industry, } \\
\text { to cope successfully with competitive forces and thus get a higher return on investment. }\end{array}$ \\
\hline [28] Fahey (1989) & $\begin{array}{l}\text { Strategy explains how the company will use its resources and capabilities to build and sustain } \\
\text { the competitive advantages that favourably influence customer purchasing decisions. }\end{array}$ \\
\hline [39] Henderson (1989) & $\begin{array}{l}\text { Strategy is the focused use of imagination and logic to respond to the environment so that as } \\
\text { a result it generates competitive advantage for the company. }\end{array}$ \\
\hline [9] Ansoff \& McDonnell (1990) & $\begin{array}{l}\text { Strategy is a set of rules for decision making to guide the behaviour of an organization. There } \\
\text { are four distinct types of rules: standards by which the present and future performance of the } \\
\text { company is measured (objectives, targets); rules for the development of relationships with the } \\
\text { external environment (product strategy and marketing, or business strategy), rules for } \\
\text { establishing relations and internal processes in the organization (organizational concept); and } \\
\text { rules by which the company shall conduct its activities in the day-to-day (operational policies). }\end{array}$ \\
\hline [6] Andrews (1991) & $\begin{array}{l}\text { Strategy is the pattern of settlement in a company that determines and reveals its objectives, } \\
\text { purposes or goals, produces the principal policies and plans to achieve these targets and } \\
\text { ascertains the scale of business that the company should get involved in, the type of economic } \\
\text { and human organization and the nature of the economic and non-economic benefits generated } \\
\text { for shareholders, employees and communities. }\end{array}$ \\
\hline [38] Henderson (1991) & $\begin{array}{l}\text { Strategy is the deliberate search for an action plan to develop and adjust the competitive } \\
\text { advantage of a company. The differences between the organization and its competitors are the } \\
\text { basis of its competitive advantage. }\end{array}$ \\
\hline $\begin{array}{l}\text { [53] Mintzberg \& Quinn } \\
\text { (1991) }\end{array}$ & $\begin{array}{l}\text { Strategy is the deliberate search for an action plan to develop and adjust the competitive } \\
\text { advantage of a company. The differences between the organization and its competitors are the } \\
\text { basis of its competitive advantage. }\end{array}$ \\
\hline $\begin{array}{l}\text { [69] Rumelt, Schendel } \\
\& \text { Teece (1994) }\end{array}$ & $\begin{array}{l}\text { Strategy is to define the direction of organizations. This includes issues of primary concern to } \\
\text { the manager, or any person who seeks the reasons for success and failure between organizations. }\end{array}$ \\
\hline $\begin{array}{l}\text { [81] Thompson \& } \\
\text { Strickland III (1995) }\end{array}$ & $\begin{array}{l}\text { Strategy is a set of competitive changes and business approaches that managers perform to } \\
\text { achieve the best performance of the company. It is the managerial plan to enhance the } \\
\text { organization's position in the market, boost customer satisfaction and achieve performance } \\
\text { targets. }\end{array}$ \\
\hline
\end{tabular}


Tab. 1: Definitions of strategy in organizational contexts (part 3)

\begin{tabular}{l|l}
\hline Author(s) & Definitions of Strategy \\
\hline [48] Miller \& Dess (1996) & Strategy is a set of plans or decisions made in an effort to help organizations achieve their objectives. \\
\hline [67] Porter (1996) & $\begin{array}{l}\text { Strategy means performing different activities to those performed by rivals or performing the } \\
\text { same activities differently. }\end{array}$ \\
\hline $\begin{array}{l}\text { [88] Wright, Kroll \& Parnell } \\
\text { (1997) }\end{array}$ & $\begin{array}{l}\text { Strategy is the set of plans from top management to achieve results consistent with the } \\
\text { organizational mission and objectives. }\end{array}$ \\
\hline [54] Mintzberg, Ahlstrand & $\begin{array}{l}\text { Strategy is the mediating force between the organization and its surroundings, focusing on } \\
\text { decisions and actions that come naturally. Strategy formation is not limited to intentional } \\
\text { processes, but can occur as a pattern of actions formalized or otherwise. }\end{array}$ \\
\hline [12] Barney (2001) & $\begin{array}{l}\text { Strategy is the theory of the firm on how to compete successfully. It also considers performance } \\
\text { as a factor influenced by strategy, as it can be considered that to compete successfully means } \\
\text { having a satisfactory performance. }\end{array}$ \\
\hline
\end{tabular}

Source: own elaboration

development fully underway in the 1960s and 1970s.

According to Porth [68], strategic management emerged as part of strategic planning, which is now regarded as one of its main instruments. It was incorporated into strategic management, which united planning and management in the same process. On the other hand, Stead and Stead [76] stated that strategic management is derived from the concept of enterprise policy. This concept explains the organization as a system in which economic resources are applied effectively with the company's functional activities coordinated around generating profit.

Once founded, strategic management expanded swiftly and produced both theoretical and practical models [22]. A broad range of models emerged out of market analysis in the 1960s, including the BCG Matrix, SWOT Model, the Experience Curve, and Portfolio Analysis, as well as important concepts such as the economic analysis of structure, behaviour and performance, distinctive competences, skills, and the so-called strategic planning systems [29], [54], [77].

Currently, strategic management is one of the most prominent and relevant areas in the management field. It constitutes a set of management actions that enable company managers to keep it aligned with its environment and on the correct path of development, thereby bringing about the achievement of its objectives and its mission [25], [40], [56], [79], [17]. Despite its importance, Boyd et al. demonstrate that strategic management has many attributes of a still immature field of study, with little consensus and low levels of productivity. This result furthermore explains the reason there are several definitions for the same concept.

According to Ansoff and McDonnell [9], strategic management constitutes a systematic approach to the management of changes, comprising: positioning the organization through strategy and planning, real time strategic response through the management of problems, and the systematic management of resistance during strategy implementation. On the other hand, Porth [68] believes that strategic management is definable as a crossprocess of formulation, implementation and evaluation of the decisions that enable organizations to define and achieve their mission and ultimately to create value.

Bowman et al. [16] strategic management focuses on issues concerning either the creation and sustainability of competitive advantage or the search for such an advantage. Furthermore, Grant [33] argued that strategic management involves a complex relationship between the organizational focus, the results obtained, and the broad spectrum of external and internal environmental variables of the organization.

According to Dess et al. [25], strategic management in an organization must become a process and a single path guiding actions throughout the organization. It consists of organizational analysis, decisions and actions creating and sustaining competitive advantage. 
These authors define four key attributes for strategic management: directed towards the overall organization objectives, includes multiple stakeholders in decision-making, requires incorporating short and long term perspectives and, involves the recognition of trade-offs between effectiveness and efficiency.

Stead and Stead [76], in turn, defined strategic management as an ongoing process involving the efforts of strategic managers to adjust the organization to the environment in which it operates while developing competitive advantages. These competitive advantages enable the company to seize opportunities and minimize environmental threats.

More generally, strategic management is a broad term that includes determining the mission and objective of the organization in the context of its external and internal environments.

\section{Phenomenography}

Phenomenography is a relatively new approach for scientific research with the first published articles appearing at the beginning of the 1980s [44]. This approach seeks to qualitatively describe the different forms by which people experience, conceptualize, perceive, and understand several aspects of a particular phenomenon. This implies that phenomenography is not concerned only about the phenomena under research, nor, indeed, exclusively with the people experiencing them. On the contrary, it focuses upon the relationship between them, i.e., the ways in which people experience or think about the respective phenomenon [23]. Hence, a phenomenographic study aims to describe the variation in how a determined phenomenon (for example, a concept) is understood, experienced or perceived by a group of people [13].

A phenomenographic method argues that individuals perceive the world in different forms as experience is always only ever partial. At any point, time, and context, people discern and experience different aspects of any phenomenon to different degrees and extents [19]. Thus, different forms of living a phenomenon can be understood in terms of which aspects of the phenomenon are perceived [4]. Therefore, the focus of this type of research is on essential aspects of the collective and variation of experience, more than the wealth of individual experiences, leading to a limited number of qualitatively different categories in the description of the investigated phenomenon [82]. Thus, according to the rules of phenomenography, the different ways of living a phenomenon are not constituted of independent forms, but rather mutually interrelated [63]. These different ways are ordered in terms of conscience inclusivity, within which more inclusive forms also represent more complex forms of experiencing the phenomenon indicated for ever greater amplitude of knowledge on the phenomenon's different aspects. In other words, an increasing number of aspects of the phenomenon are perceived as potentially different [4] articulating internal logical relationships between different forms of living and experiencing such a phenomenon [82].

Traditionally, the object of phenomenography research study has been described as variations in the human sensing and understanding of conceptions [44] or, more recently, conscience or ways of testing a determined phenomenon [87]. The results are analytically represented as a series of meanings (qualitatively different) or even some ways of testing a phenomenon, called "categories" in order to distinguish between empirically interpreted categories and the hypothetical experience they represent, including also the structural relationships that connect these different forms of testing. These relations provide a briefing on the relations between different ways of experiencing a phenomenon [4].

The focus of phenomenography research on the collective experience (and not the individual) is usually misunderstood and deserves clarification. Marton [44] advises on definitions of the diverse forms of understanding reality. According to this author, these perspectives are not conceived by phenomenography as individual perceptions but rather as categories that depict a collective conception of a phenomenon. That is, phenomenography research aims to explore gamma meanings within a group as a group, and not the gamma meanings for each individual within the group [70]. Furthermore, Svensson [80] argues that the varieties of forms by which people test these phenomena are referred to as agreements and susceptible for presentation as description categories for the phenomenon in question.

These categories establish the base for developing a hierarchy of agreements, 
themselves forming a model that describes the phenomenon in its totality. This model contains a set of categories hierarchically structuralized around the phenomenon under study [36]. Consequently, the researcher aims at constituting a logical structure relative to different meanings. The categories constituted by researchers for representing the different forms of living a phenomenon are seen as representing a structuralized set - the model. This provides a means of grasping the collective human experience of the holistic phenomena despite the fact the same phenomenon can be perceived in different forms by different people and in different circumstances. Ideally, the results represent all the gamma of possible forms of living a specific phenomenon, in a specific time, for the population collectively represented by the group [4].

In practical terms, phenomenography has proven efficient when deployed to witness decisions on education programs and applied in two distinct forms [4]: (i) to identify a variation in the agreement on one determined concept (involving the identification of the main characteristics of concepts that alumni do or do not obtain to discern their understanding of the phenomenon); and (ii) to project an education program that maximizes alumni opportunities to gain a full understanding of a concept based on a prior evaluation of knowledge on the phenomenon. Correspondingly, we approach phenomenography as a research method that focuses on concepts explaining phenomena as lived by individuals and of value in practically all educational areas [5].

\section{Methodology}

In accordance with the principles of phenomenography (the collective analysis of individual experiences), proposed by Marton [44], described in the introduction to this study and the methodological decisions made explicit in the work of Shanahan and Gerber [75], this research project adopted the phenomenographic methodology. This is characterized as qualitative, exploratory and cross-sectional [34], with data collection carried out by personal interviews with structured questionnaires. All methodological decisions described in the sequence (universe and sample research, collection and analysis of data) were adapted from the study of Shanahan and Gerber [70].
However studies on the field of education [5], [13], [19], [36], [63], [82] and on consumer behaviour [87] also played their role in the methodological decisions taken over the course of this research project.

To attain our study objectives, we examined students taking degrees in management at public universities in Portugal. Their curricula programs feature strategy and/or strategic management subjects. The choice of Portuguese public universities derives from the fact that they represent about $60 \%$ of higher education students in Portugal [64]. All thirteen universities were invited to participate. Of these, five universities expressed interest: University of Beira Interior (UBI), University of Coimbra (UC), University of Évora (UE), University of Minho (UM), and University of Porto (UP). The questionnaires were sent to these universities and then completed in the classroom and returned completed to the researchers.

The choice of this target group derived from their being on the verge of graduation and in a few months will become the youngest managers in the Portuguese market. This means they might be expected to be the management professionals with the most up-to-date knowledge on the issues involving organizational management, including strategy and strategic management. The sample gathered focuses on the students present in classrooms on the days of the application of the research questionnaire and that had been passed approved in these subjects. This type of sample appears as nonprobabilistic, intentional, for trial [34]. It should be noted that the results presented here represent only a proportion of management students in Portugal. To achieve a broader representation of Portuguese management students, it would be necessary to apply the same research in other universities.

For the purposes of data collection, we deployed a questionnaire with six open questions, which aimed to identify respondent perceptions as to their own definitions of strategy and strategic management. The final questionnaire was the following:

1. Based on your own experience, what does strategy mean to you?

2. Using your own words, what is your definition of strategy?

3. According to your point of view, give at least three examples of strategies. 
4. Quote means of applying your concept of business strategy.

5. What the meaning of strategic management? Give examples.

6. Explain what it means to strategic management. How can you apply this concept in organizations?

Significantly, each subject studied is linked to two questions (definition of strategy, examples of strategies, and definition and examples of strategic management). This is the main feature of the phenomenography method and aims to make the interviewee think more precisely about what his/her real insight is on the phenomenon studied [2], [3], [4]. Data collection was carried out during the period between April and June 2009. After the application of research tools, the same, duly completed, were returned to the researchers who then conducted an initial questionnaire assessment: UBI (42 completed questionnaires with 38 considered valid); UC (29 completed questionnaires with 28 valid); UE (25 questionnaires returned, all valid); UM (of 48 completed questionnaires, 33 proved valid); and UP (22 questionnaires returned, all valid). In sum, 166 questionnaires were completed, and 146 were validated and incorporated into the analytical process. The next step was to transfer the data collected for software analysis.

With all answers in digital format, content analysis was used for data analysis aiming to identify definitions of strategy and strategic management through coding [24], with the aid of the Atlas/ti software [57].This type of analysis searches for regularities and variability based on replications of observations or statements entailing the quantification of qualitative data [24]. In this case, the codes were initially established by the words most common in the definitions of strategy and strategic management, as well as the types of strategy and strategic management cited by the students. With the data entered into the Atlas/Ti software, the codes were also inserted into the system. This grouped interviewee statements on regularities and similarities according to the established coding. This meant we were able to collectively handle and process the interviews thereby resulting in a ranking of codes present in the data collected from the respondents (from the most present to the least present).

\section{Results Analysis}

The beginning of the questionnaire asked only two personal questions of respondents: age and gender. The age of respondents ranged from 20 to 54 years, with the average age of 22.2 , with about $74 \%$ of respondents less than 24 years old. This means that the majority of future managers entering the market in the coming months have little or no experience and basically rely on the knowledge acquired at university. This further justifies the importance of this research as it puts forward an understanding of the relationship that students make between the theory learned and the practices they are to undertake thus enabling the higher education institution (HEI) to tailor their degrees to market necessities. With regard to gender, the research involved 81 men and 65 women, which proved to bear no significant relevance to the answers returned.

Considering the questionnaire responses, we need to make one comment before presenting the data analyzed. Thus, in the first two questions, which correspond to the concept of strategy, most respondents gave detailed answers, filling all the spaces for each question. This allowed more detailed analysis on the understanding of the strategy concept held by management students. Concerning the questions dealing with types of strategies (questions 3 and 4) and the concept and types of strategic management (questions 5 and 6), the same respondents were too general and objective in their responses, which did not allow as thorough analysis as that on the strategy concept.

The first two questions dealt with the personal understanding of each respondent on the subject of strategy. None of those interviewed cited strategy outside the field of management. There were no references to military strategies, policies, among others. This demonstrates that the topic discussed currently enters the field of management, at least among these representatives of future organizational managers. According to respondents, strategy holds different connotations (Table 2). 


\section{Tab. 2: Definitions of strategy based on the surveyed (part 1)}

\begin{tabular}{l} 
Definition \\
\hline 1. [...] Strategy is the \\
development of plans, \\
policies and practices to \\
achieve the company \\
objectives [...] (110 similar \\
responses).
\end{tabular}

\section{Analysis}

This definition of strategy was the most frequent in the responses collected. One reason is that many authors approach strategy in this sense [6], [9], [20], [21], [32], [43], [46], [53], [59], [61], [71], [78], [81], [84], [85]. It is presented as a more complete definition and involving the organization as a whole. Internalising this view of strategy ensures the manager follows a logical path in strategic business development in planning, establishing guidelines and policies, and encouraging practice able to achieve organizational goals. What this definition lacks is the relationship with the external environment because it reduces strategy to the internal company environment.

2. [...] Strategy is the way in which the company should behave or act in the market and relate to its external environment [...] (57citations).

In other words, it is marketplace company policy to compete and survive, based on forward planning. This proved to be the second most common response, also due to several authors citing the environment external to the organization as critical to the company's strategic development [7], [8], [9], [10], [18], [26], [37], [38], [39], [45], [50], [54], [65], [67], [71], [72]. It is indeed a fact that a company is related to its external environment and all organizational strategic actions should consider aspects related to the respective prevailing environment. Thus, it is important to note that most new managers are aware that a company should be focused on the market where it operates.

\section{3. [...] Strategy is the} responsibility of senior company management and the result of their decisions [...] (33 cases).

4. [...] Strategy is to have medium and long term goals. Only a few respondents [...] (32 replies).

5. [...] Strategy is
a guideline for structuring
the company [...]
(30 citations).

6. [...] Strategy is a means of achieving business success [...] (cited 19 times).

7. [...] Strategy is the vision and mission of the company [...]. (cited 18 times).

8. [...] Strategy is an indication of what direction the company should take [...] (cited by 15 respondents).
According to the respondent answers, the relationship between strategy and top management is not often quoted by authors. The high correlation between management and strategy is referred to by different authors [48], [49], [52], [87]. It should be noted that a common strategy in the studies is that this issue is traditionally handled by the managers running the organization, although most existing concepts are not very explicit about this.

Respondents stated that strategy is linked to corporate objectives for medium and long term company goals; similar to that stated in the literature, where the definitions of strategy seldom mention the same relationship with its medium and long term goals [1], [9], [21]. In this sense, one can see that the classical school and its followers [86] is that which prescribes the need to plan strategically for the medium and long term.

Quoted by Ansoff and McDonell [9], Bracker [18], Drucker [26], Fahey [28], and Michel [47], defining strategy as guiding organizational structure shows that the company's resources and capabilities are determined according to organizational strategic options [11], and was not prominent among respondent answers. However, in accordance with the responses already given, we may consider that the specific structure necessary for the company to achieve its objectives is included within the scope of senior management decisions and planning strategies, words attaining greater incidence among respondents.

Strategy as the means of achieving organizational success was previously put forward by Barney [11], Porter [66], and Wright et al. [87]. This type of definition relates company success to the effectiveness of its strategy and its implementation (through activities and practices).

Also derived from the school of planning [54], the company mission and vision are proposed by Newman and Logan [59], Steiner and Miner [78], and Wright et al. [87]. This type of response by new managers expresses a certain difficulty in converting strategy into the organizational reality.

This response is a simplification of the others. The path to be taken refers to the medium and long term, decisions and senior management responsibilities, the mission and vision of the organization, leading to planning, policies and practices. This reductionist definition has already been presented by Rumelt et al. [69]. 


\section{Tab. 2: Definitions of strategy based on the surveyed (part 2)}

\begin{tabular}{|c|c|}
\hline Definition & Analysis \\
\hline $\begin{array}{l}\text { 9. [...] Strategy depends } \\
\text { on the competitive } \\
\text { advantages of the } \\
\text { company [...] (15 citations). }\end{array}$ & $\begin{array}{l}\text { The identification of organizational competitive advantages features in the definitions of strategy } \\
\text { put forward by Ansoff [7], Cannon [20], Henderson [38], [39], and Newman and Logan [59]. } \\
\text { Whereas the company's competitiveness is based on its advantages over competitors, it should } \\
\text { be considered that these advantages are what influence the choice of a particular strategy and } \\
\text { so the first step in choosing the strategy is to identify the company's competitive advantages, } \\
\text { as pointed out by some of the respondents. }\end{array}$ \\
\hline $\begin{array}{l}\text { 10. [...] Strategy is based } \\
\text { on the collection and } \\
\text { analysis of company and } \\
\text { stakeholder information }[\ldots] \\
\text { (13 citations). }\end{array}$ & $\begin{array}{l}\text { The decision of which strategy to follow depends on the collection and analysis of organizational } \\
\text { information (and including its external environment). This analysis is performed by the top } \\
\text { management of organizations, that is, in a setting that complements the fact that strategy is } \\
\text { linked to the individuals running companies. }\end{array}$ \\
\hline $\begin{array}{l}\text { 11. [...] Strategy involves } \\
\text { the entire company [...] } \\
\text { (5 citations). }\end{array}$ & $\begin{array}{l}\text { Uncommon among the definitions of strategy found in the literature, the involvement of the entire } \\
\text { organization in the respective strategy was previously cited by Ackoff [1], Glueck [32], and } \\
\text { Mintzberg and Quinn [53]. Though not often referred to by authors who conceptualize the } \\
\text { strategy, we see that it increases the chance of success when all members of the company fully } \\
\text { participate in the chosen strategy. This fact was pointed out by only } 5 \text { respondents. }\end{array}$ \\
\hline $\begin{array}{l}\text { 12. [...] Strategy is a way } \\
\text { to acquire customers }[\ldots] \\
\text { (2 citations). }\end{array}$ & $\begin{array}{l}\text { A subject virtually forgotten by both respondents and the literature, acquiring customers as } \\
\text { a result of organizational strategy does merit mention by Fahey [28]. This correspondingly posits } \\
\text { that one major objective behind developing organizational strategies is attracting and retaining } \\
\text { customers, who generate the revenue necessary for the company to attain its financial results, } \\
\text { besides fulfilling its mission and vision. Thus, attracting and retaining customers is very much } \\
\text { linked to company marketing departments and often overlooked by other functional areas. } \\
\text { Market orientation should align all participants towards the organization's customers. }\end{array}$ \\
\hline
\end{tabular}

Source: own elaboration

In summary, these twelve understandings of strategy expressed by managers new to the market amount to a vision of what strategy means to them. In addition to the set of views held on the subject, the term strategy was defined as:

[...] Based on the collection and analysis of information internal and external to the company, in addition to the early identification of competitive organizational advantages, strategy is the set of decisions taken by senior company management (the path to follow, objectives in the medium and long term, the necessary structure, mobilization of the entire organization, the company mission and vision) that leads to the development of internal practices, action plans, policies and guidelines, which aim to improve the organization's relationship with its external environment, geared to market. This results in the acquisition and retention of customers, leading to organizational success [...].

Thus, this ranges from a narrower vision to a broader view. Figure 1 sets out the understanding of strategy according to these managers and how it closely approximates the school of Planning, previously explained and described by Mintzberg et al. [54]. This school approaches the formation of strategy as a formal organisational process termed strategic planning. Among the main authors adopting the principles of this school are Ansoff [7], [8], Schendel and Hatten [71], Ackoff [1], McNichols [46], and Ansoff and McDonell [9]. Considering the answers obtained, respondents perceive that organizational strategy should be formalized by the setting of rules by the organization's senior managers. This would seem to be what they most expect to encounter in real organizations. 


\section{Fig. 1: Set of visions on the definition of strategy}

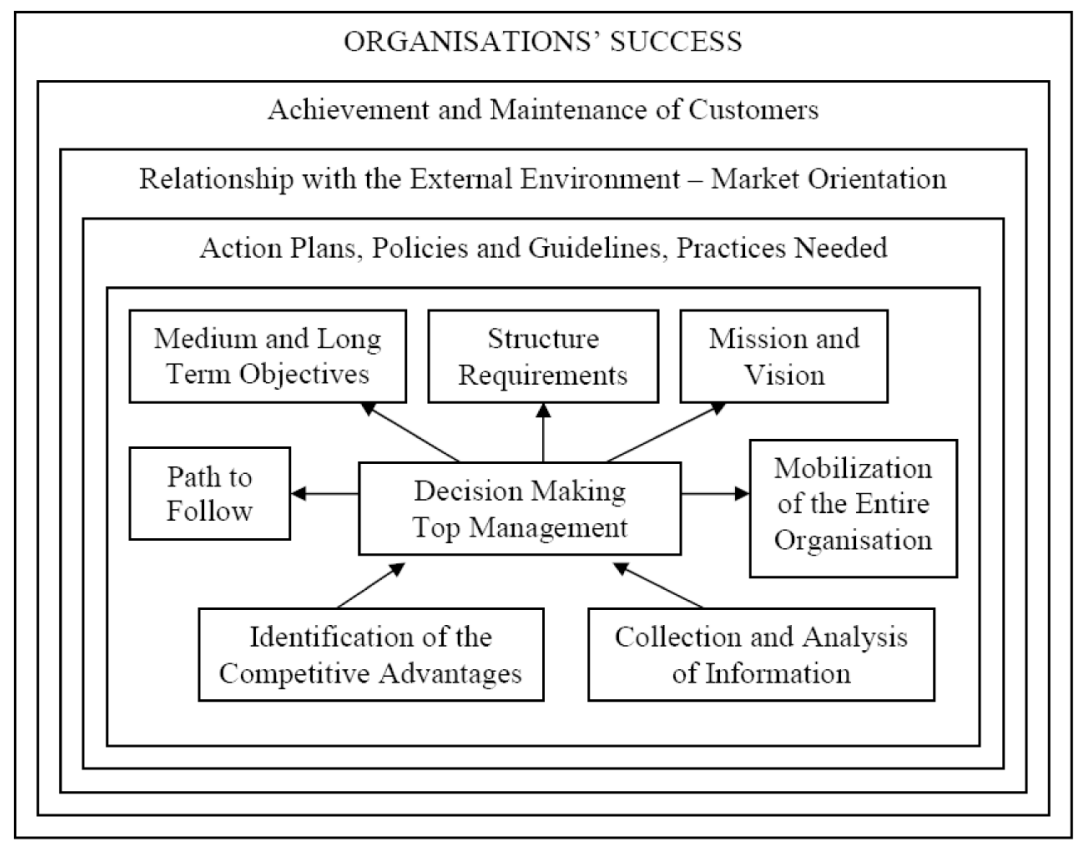

Source: own elaboration

Following the questionnaire, interviewees were requested they provide examples of strategies. Porter's [65] generic competitive strategies (focus, differentiation, and cost leadership), and strategies for diversification, internationalization, and vertical integration stood out and were mentioned by most respondents. However, when asked to translate these strategies into real-world examples (at least three), most respondents left this question blank. Others cited:

[...] To improve the quality of products / services, to plan the location of the business, innovate in products, use resources appropriately, understand and adapt to the market where the company operates, to inform strategies for employees, develop motivation and the involvement of employees, use marketing, improve the company's technologies, enhance the brand of products, focus on customer service, develop action plans to build a good corporate image, increase the radius of company action, explore new markets, invest in employee training, invest in information technology, strategic alliances and cooperation, focus on e-commerce, hire skilled managers, do market research [...].

Indeed, some difficulty in translating the theoretical approaches learned during their degrees to the business environment was noted in the respondent responses. This fact is probably due to little or no working experience on behalf of students answering the survey, an important indicator both for the institution and its lecturers as well as other higher education entities running degrees in management. Students may be graduating with a good definition of an important concept (strategy) but they are confronting difficulties in applying it to organizations.

The final section of the questionnaire dealt with strategic management, definitions and examples. When concerning the definition of the term, most citations divided up between two 
definitions: (1) the organization of policies and action plans to enact and implement the company strategy; and (2) the application and implementation of strategic planning. Both definitions are similar and close to the broad definition of Wright et al. [87] and match organizational reality. Other definitions cited by respondents converge around the definitions mentioned:

[...] It establishes common goals for all participants in the organization, strategic control, its strategic direction, competitive advantages, the management of internal and external organizational environments, and the management of resources, objectives, and business practices [...].

A point to note is that many respondents confused strategy with strategic management. There were 37 responses where respondents displayed difficulties in differentiating between the concepts of strategy and strategic management. Thus, it is possible to infer that a percentage of future managers, despite having studied strategy and strategic management, do not differentiate one concept from the other, and this should be a cause for reflection among the lecturers teaching these concepts.

With regard to examples of strategic management activities, it became once again clear the difficulty of interpreting the definition in real situations. The examples were:

[...] The formalization of the company's strategy, management of company growth and internationalization, considering the needs of the local market, choosing a market to operate, the organization's adaptation to the environment where it is located; internal analysis (resources and capabilities), identification of competitive advantages, price management and product mix, quality management, innovation and human resources, establishing and managing partnerships and cooperation agreements between organizations [...].

There were a few examples cited by students, many of whom defined strategic management but offered no examples. Again, it is noticeable that students find it difficult to translate their theoretical definitions into organizational reality.

\section{Final Considerations}

Given that the topics strategy and strategic management are relevant fields for contemporary organizations, it is of great importance for the management of organizational knowledge to identify what future managers actually understand about these issues. In order to reveal the understanding of management students as to the meaning of the concepts of strategy and strategic management - the main objective of this study - it was concluded that there is an understanding of what each means, although it appears that these future managers have some difficulty in translating these concepts into the reality of organizations. This confirms the importance of an effort to systematize the concepts of strategy and strategic management by researchers in this scientific field, as argued for by Parayitam [62]. Only with the convergence of studies in the area around the same concept definition of the phenomenon might help in conveying a better understanding of this important organizational aspect for management practitioners and a significant and essential factor for organizational knowledge management.

Our findings also identify how no concept of strategy prevails in student responses. Instead, what we found was that the understanding of strategy is a mixing of concepts displayed by various authors dealing with this issue. When relating to strategic management, the definition found was very close to that proposed by Wright et al. [87]. We observed how the majority of respondents understand strategy and the establishment of company policies, guidelines, practices and action plans designed to attain a common goal and to mediate the organization's relationship with its external environment. Observing our model (figure 1), respondents described the path taken in establishing strategies begins with the collection and analysis of information on the company and prior identification of the company's competitive advantages, through senior management decisions (on macro-objectives, ways forward, mission and vision, structures, and the mobilization of all employees), which generate the internal company actions able to deliver the chosen strategy. These internal actions are reflected in the external environment where the organization is inserted. The majority of respondents reached this far. 
Others returned a more comprehensive vision and saw in the concept of strategy the opportunity to acquire and keep customers, resulting in organizational success.

Our model explains the definition of strategy in the vision of young managers on the cusp of entering the market and represents another of the specific objectives of this research project. There was also confusion over the meaning of strategic management. In several cases, there was a clear mix up in the definitions of strategy and strategic management. Furthermore, this statement does impact on managers involved in organizational knowledge processes given if there is no shared perception of strategic management among managers, there is the need to unify their understanding to ensure decision making is based on the same principles [60].

Despite this finding, it was concluded that the definition of strategic management presented by those students who managed to differentiate the two terms is close to that presented in the literature. Although they are terms that can cause some confusion, most future managers did know the difference between strategy and its management. More could be done to explore the next phase of research, especially concerning the artefact this round generated. Additionally, a before and after comparison of student perceptions on strategy and strategic management would prove of relevance in generating insights into the effects of education.

In terms of limitations, it is important to emphasize that this is a study of a qualitative nature, with a statistically unrepresentative sample. Therefore, while the results contribute to the realities of the universities surveyed, they cannot be generalized. Therefore, the statistical validation of the proposed model is recommendable along with the replication of the research presented here in other HEl, both in Portugal and internationally, and the confirmation of the factors making up the definition of strategy in the vision of the future managers. Concerning the topic of strategic management, further studies may serve to refine the current concept.

Furthermore, management student lecturers engaged in the theme of strategy and strategic management should strive to translate into real-world examples in teaching the concepts inherent to both topics. This relationship between theory and practice can contribute to enhancing the competences of new market managers; after all, we do here demonstrate that there is a need for adjustments in the teaching of strategy related subjects on management degrees. A balance between the current schools of thought on the concept (to thus avoid choosing a single school and following only what it prescribes) and an approach towards the realities of practical managerial and company life represent challenges for both lecturers and researchers in the field.

This research was supported by the Portuguese Science Foundation through NECE - Núcleo de Investigação em Ciências Empresariais (Programa de Financiamento Plurianual das Unidades de I\&D da FCT Fundação para a Ciência e Tecnologia, Ministério da Ciência, Tecnologia e Ensino Superior/Portugal).

\section{References}

[1] ACKOFF, R. Redesigning the future. New York: John Wiley \& Sons, 1974. ISBN 04-7100-296-8.

[2] AKERLIND, G. Principles and practice in phenomenographic research. In International Symposium on Current Issues in Phenomenography. Canberra/Australia, 2002. ISSN 0729-4260.

[3] AKERLIND, G. Variation and commonality in phenomenographic research methods. Higher Education Research \& Development. 2005, Vol. 24, Iss. 4, pp. 321-334. ISSN 1469-8366.

[4] AKERLIND, G. A phenomenographic approach to developing academics' understanding of the nature of teaching and learning. Teaching in Higher Education. 2008, Vol. 13, Iss. 6, pp. 633-644. ISSN 1470-1294.

[5] ANDRETTA, S. Phenomenography: a conceptual framework for information literacy education. Aslib Proceedings: New Information Perspectives. 2007, Vol. 59, Iss. 2, pp. 152-168. ISSN 0001-253X.

[6] ANDREWS, K. The concept of corporate strategy. In MINTZBERG, H. and J. QUINN (Eds.). The strategy process, concepts, contexts, cases. New Jersey: Prentice-Hall, 1991. pp. 128-141. ISBN 01-3047-913-6.

[7] ANSOFF, H. Corporate strategy: An analytic approach to business policy for growth and expansion. New York: McGraw-Hill, 1965. ISBN 00-7002-111-2. 
[8] ANSOFF, H. Strategic management. London: Macmillian, 1979. ISBN 04-7026-585-X.

[9] ANSOFF, H., MCDONNELL, E. Implanting strategic management. New Jersey: Prentice-Hall, 1990. ISBN 01-3451-808-X.

[10] BARNARD, C. The function of the executive. Boston: Harvard University Press, 1938. ISBN 067432-800-0.

[11] BARNEY, J. Firm resource and sustained competitive advantage. Journal of Management. 1991, Vol. 17, Iss. 1, pp. 99-120. ISSN 0149-2063. [12] BARNEY, J. Resource-based theories of competitive advantage: $\mathrm{A}$ ten years retrospective on the resource based view. Journal of Management. 2001, Vol. 27, Iss. 1, pp. 643-650. ISSN 0149-2063. [13] BERGLUND, A. et al. Learning computer science: perceptions, actions and roles. European Journal of Engineering Education. 2009, Vol. 34, Iss. 4, pp. 327-338. ISSN 0304-3797.

[14] BHALLA, A., LAMPEL, J., HENDERSON, S. and WATKINS, D. Exploring alternative strategic management paradigms in high-growth ethnic and non-ethnic family firms. Small Business Economics. 2009, Vol. 32, Iss. 1, pp. 77-94. ISSN 1573-0913. [15] BIERLY, P. and HÄMÄLÄINEN, T. Organizational learning and strategy. Scandinavian Journal of Management. 1995, Vol. 11, Iss. 3, pp. 123-141. ISSN 0956-5221.

[16] BOWMAN, E., SINGH, H. and THOMAS, H. The domain of strategic management: History and evolution, In PETTIGREW, A., THOMAS, H. and WHITTINGTON, R. (Eds.). Handbook of strategy and management. London: Sage, 2002. pp. 31-51. ISBN 07-6195-893-2.

[17] BOYD, B., FINKELSTEIN, S. and GOVE, S. How advanced is the strategy paradigm? The role of particularism and universalism in shaping research outcomes. Strategic Management Journal. 2005, Vol. 26, Iss. 1, pp. 841-854. ISSN 0143-2095.

[18] BRACKER, J. The historical development of the strategic management concept. Academy of Management Review. 1980, Vol. 5, Iss. 1, pp. 219-224. ISSN 0363-7425.

[19] BRADBEER, J., HEALEY, M. and KNEALE, P. Undergraduate geographers' understandings of geography, learning and teaching: A phenomenographic study. Journal of Geography in Higher Education. 2004, Vol. 28, Iss. 1, pp. 17-34. ISSN 0309-8265.

[20] CANNON, J. Business strategy and policy. New York: Harcourt, Brace \& World, 1968. ISBN 65-4317-252-0.
[21] CHANDLER, A. Strategy and structure: Chapters in the history of the American industrial enterprise. Cambridge: MIT Press, 1962. ISBN 15-8798-198-X. [22] CHU, P. and TSE, O. The art of war and strategic management. Journal of Management Education. 1992, Vol. 16, Iss. 4, pp. 43-53. ISSN 1052-5629.

[23] DALL'ALBA, G. et al. Assessing understanding: A phenomenographic approach. Research in Science Education. 1989, Vol. 19, Iss. 1, pp. 57-66. ISSN 1573-1898.

[24] DENSCOMBE, M. The good research guide: For small-scale social research projects. 2nd ed. Philadelphia: McGraw-Hill, 2003. ISBN 03-3522968-9.

[25] DESS, G., LUMPKIN, G. and EISNER, A. Strategic management. 3rd ed. New York: McGraw-Hill, 2007. ISBN 00-7340-498-5.

[26] DRUCKER, P. The practice of management. New York: Harper \& Brothers, 1954. ISBN 00-6091316-9.

[27] ERIKSSON, P. and LEHTIMÄKI, H. Strategy rhetoric in city management: How the presumptions of classic strategic management live on? Scandinavian Journal of Management. 2001, Vol. 17, Iss. 2, pp. 201-223. ISSN 0956-5221.

[28] FAHEY, L. The strategic planning management reader. Englewood Cliffs/New Jersey: Prentice-Hall, 1989. ISBN 01-3851-759-2.

[29] FAIRHOLM, M. and CARD, M. Perspectives of strategic thinking: From controlling chaos to embracing it. Journal of Management \& Organization. 2009, Vol. 15, Iss. 1, pp. 17-30. ISSN 1833-3672.

[30] GHEMAWAT, P. Strategy and the business landscape: Core concepts. 2nd ed. Englewood Cliffs/New Jersey: Prentice-Hall, 2005. ISBN 01-3028-976-0.

[31] GILLESPIE, T. and PARRY, R. Students as employees: Applying performance management principles in the management classroom. Journal of Management Education. 2009, Vol. 33, Iss. 5, pp. 553-576. ISSN 1052-5629.

[32] GLUECK, W. Business policy, strategy formation, and management action. 2nd ed. New York: McGraw-Hill, 1976. ISBN 00-7023-514-7.

[33] GRANT, R. Corporate strategy: Managing scope and strategy content. In PETTIGREW, A., THOMAS, H. and WHITTINGTON, R. (Eds.). Handbook of strategy and management. London: Sage, 2002. pp. 72-97. ISBN 07-6195-893-2.

[34] HAIR, J., BABIN, B., MONEY, A. and SAMOUEL, P. Essentials of business research 
methods. New Jersey: John Wiley \& Sons, 2003. ISBN 04-7127-136-5.

[35] HÄKANSSON, H. and SNEHOTA, I. No business is an island: The network concept of business strategy. Scandinavian Journal of Management. 2006, Vol. 22, Iss. 3, pp. 256-270. ISSN 0956-5221.

[36] HALLETT, F. The postgraduate student experience of study support: A phenomenographic analysis. Studies in Higher Education. 2010, Vol. 35, Iss. 2, pp. 225-238. ISSN 0307-5079.

[37] HAMBRICK, D. Operationalizing the concept of business-level strategy in research. Academy of Management Review. 1980, Vol. 5, Iss. 1, pp. 567-575. ISSN 0363-7425.

[38] HENDERSON, B. The origin of strategy. Harvard Business Review. 1989, Vol. 67, Iss. 1, pp. 139-143. ISSN 0017-8012.

[39] HENDERSON, B. The origin of strategy. In PORTER, M. and MONTGOMERY, C. (Eds.). Strategy: Seeking and securing competitive advantage. Boston: Harvard Business School Publishing Division, 1991. pp. 82-94. ISBN 08-7584-243-7.

[40] JONES, J. Application of decision support concepts to strategic management. Journal of Management Education. 1981, Vol. 6, Iss. 1, pp. 44-45. ISSN 1052-5629.

[41] KRAUS, S., KAURANEN, I. and RESCHKE, C. Identification of domains for a new conceptual model of strategic entrepreneurship using the configuration approach. Management Research Review. 2010, Vol. 34, Iss. 1, pp. 58-74. ISSN 2040-8269.

[42] KUVAAS, B. and KAUFMANN, G. Individual and organizational antecedents to strategic-issue interpretation. Scandinavian Journal of Management. 2004, Vol. 20, Iss. 3, pp. 245-275. ISSN 0956-5221.

[43] LEARNED, E., CHRISTENSEN, R., ANDREWS, K. and GUTH, W. Business policy: Text and cases. Homewood/Illinois: Irwin, 1969. ISBN 76-1459-813-0.

[44] MARTON, F. Phenomenography: Describing conceptions of the world around us. Instructional Science. 1981, Vol. 10, Iss. 1, pp. 177-200. ISSN 0020-4277.

[45] MCCARTHY, D., MINICHIELLO, R. and CURRAN, J. Business policy and strategy: Concepts and readings, Homewood/Illinois: Irwin, 1975. ISBN 02-5601-680-1.

[46] MCNICHOLS, T. Policy making and executive action. 5th ed. New York: McGraw-Hill, 1977. ISBN 00-7045-688-7.
[47] MICHEL, K. Design of an intrafirm management development programme for strategic managers. In ANSOFF, H., DECLERCK, R. and HAYES, R. (Eds.). From strategic planning to strategic management. London: John Wiley \& Sons, 1976. pp. 152-171. ISBN 04-7103-223-9.

[48] MILLER, D. and DESS, G. Strategic management. 2nd ed. New York: McGraw Hill, 1996. ISBN 00-7042-791-7.

[49] MINTZBERG, H. The science of strategymaking. Industrial Management Review. 1967, Vol. 8, Iss. 2, pp. 71-81. ISSN 0263-5577.

[50] MINTZBERG, $\mathrm{H}$. The structuring of organizations. Englewood Cliffs/New Jersey: Prentice-Hall, 1979. ISBN 01-3855-270-3.

[51] MINTZBERG, H. The strategy concept I: Five P's for strategy. California Management Review. 1987, Vol. 30, No. 1, pp. 11-24. ISSN 0008-1256. [52] MINTZBERG, H. and MCHUGH, A. Strategy formation in an adhocracy. Administrative Science Quarterly. 1985, Vol. 30, Iss. 1, pp. 160-197. ISSN 0001-8392.

[53] MINTZBERG, H. and QUINN, J. The strategy process: Concepts, contexts and cases. 2nd ed. Englewood Cliffs/New Jersey: Prentice-Hall, 1991. ISBN 01-3851-916-1.

[54] MINTZBERG, H., AHLSTRAND, B. and LAMPEL, J. Strategy safari: A guided tour through the wilds of strategic management. New York: Free Press, 1998. ISBN 06-8484-743-4.

[55] MOORE, M. Managing for value: Organizational strategy in for-profit, nonprofit, and governamental organizations. Nonprofit and Voluntary Sector Quarterly. 2000, Vol. 29, Iss. 1, pp. 183-204. ISSN 0899-7640. [56] MORRIS, R. and JOHNSON, B. Computerization in the strategic management course: Current status and future directions. Journal of Management Education. 1992, Vol. 16, Iss. 4, pp. 461-478. ISSN 1052-5629.

[57] MUHR, T. Atlas/ti, release 1. In WEITZMAN, E. and MILES, M. (Eds.). Computer programs for qualitative data analysis. Thousand Oaks/California: Sage, 1995. pp. 217-229. ISBN 08-0395-536-7.

[58] NADLER, D. and TUSHMAN, M. Designing organizations that good fit: A framework for understanding new architectures. In NADLER, D., GERSTEIN, M. and SHAW, R. (Eds.). Organizational architecture: Designs for changing organizations. San Francisco: Jossey-Bass, 1992. pp. 45-62. ISBN 15-5542-443-0.

[59] NEWMAN, W. and LOGAN, J. Strategy, policy and central management. Cincinatti: South-Western Publishing, 1971. ISBN 00-2072-409-0. 
[60] OBEMBE, D. Understanding individual action: when employees contravene management directives to foster knowledge sharing. Management Research Review. 2010, Vol. 33, Iss. 6, pp. 656-666. ISSN 2040-8269.

[61] PAINE, F. and NAUMES, W. Strategy and policy formation: An integrative approach. Philadelphia: Saunders. ISBN 47-2938-411-0.

[62] PARAYITAM, S. The effect of competencebased trust between physicians and administrative executives in healthcare on decision outcomes. Management Research Review. 2010, Vol. 33, Iss. 2, pp. 174-191. ISSN 2040-8269.

[63] PARTINGTON, D., YOUNG, M. and PELLEGRINELLI, S. Understanding program management competence: A phenomenographic study. In Academy of Management Annual Meeting. Anaheim (CA). 2003. ISSN 1543-8643.

[64] PORTELA, M. et al. Evaluating student allocation in the Portuguese public higher education system. Higher Education. 2008, Vol. 56, Iss. 1, pp. 185-203. ISSN 0018-1560.

[65] PORTER, M. Competitive strategy: Techniques for analyzing industries and competitors. New York: Free Press, 1980. ISBN 00-2925-360-8. [66] PORTER, M. Competitive advantage: Creating and sustaining competitive performance. New York: Free Press, 1985. ISBN 00-2925-0900-0.

[67] PORTER, M. What is strategy? Harvard Business Review. 1996, Vol. 74, Iss. 6, pp. 61-78. ISSN 0017-8012.

[68] PORTH, S. Strategic management: $A$ crossfunctional approach. New Jersey: Prentice Hall, 2002. ISBN 01-3042-213-4.

[69] RUMELT, R., SCHENDEL, D. and TEECE, D. Fundamental issues in strategy. In RUMELT, R., SCHENDEL, D. and TEECE, D. (Eds.). Fundamental issues in strategy: $A$ research agenda. Boston: Harvard Business School Press, 1994. pp. 9-47. ISBN 08-7584-343-3.

[70] SANDBERGH, J. Are phenomenographic results reliable? Higher Education Research \& Development. 1997, Vol. 16, Iss. 2, pp. 203-212. ISSN 0729-4360.

[71] SCHENDEL, D. and HATTEN, K. Business policy or strategic management. In MITCHELL, V., BARTH, R. and MITCHELL, F. (Eds.). Academy of Management Proceedings. Boston: Little Brown, 1972. pp. 56-72. ISSN 0896-7911.

[72] SCHENDEL, D. and HOFER, C. Strategic management. Boston: Little Brown, 1979. ISBN 03-1677-312-3.
[73] SCHNAARS, S. Marketing strategy: A customer-driven approach. New York: Free Press, 1991. ISBN 002927-953-4.

[74] SCHNEIDER, M. and LIEB, P. The challenges of teaching strategic management: Working toward successful inclusion of the resource-based view. Journal of Management Education. 2004, Vol. 28, Iss. 2, pp. 170-187. ISSN 1052-5629.

[75] SHANAHAN, P. and GERBER, R. Quality in university student administration: Stakeholder conceptions. Quality Assurance in Education. 2004, Vol. 12, Iss. 4, pp. 166-174. ISSN 0968-4883.

[76] STEAD, J. and STEAD, W. Sustainable strategic management: An evolutionary perspective. International Journal of Sustainable Strategic Management. 2008, Vol. 1, Iss. 1, pp. 62-81. ISSN 1753-3619.

[77] STEEN, J. Actor-network theory and the dilemma of the resource concept in strategic management. Scandinavian Journal of Management. 2010, Vol. 26, Iss. 3, pp. 324-331. ISSN 0956-5221.

[78] STEINER, G. and MINER, J. Management policy and strategy: Text, readings and cases. New York: Macmillan, 1977. ISBN 00-2416-750-9. [79] STEINTHORSSON, R. and SÖDERHOLM, A. Strategic management as multi-contextual sensemaking in intermediate organizations. Scandinavian Journal of Management. 2002, Vol. 18, Iss. 2, pp. 233-248. ISSN 0956-5221.

[80] SVENSSON, L. Theoretical foundations of phenomenography. Higher Education Research \& Development. 1997, Vol. 16, Iss. 2, pp. 159-171. ISSN 1469-8366.

[81] THOMPSON, A.A. and STRICKLAND A.J. Strategic management: Concepts and cases. 8th ed. Homewood/Illinois: Irwin, 1995. ISBN 00-7231-499-0.

[82] TRIGWELL, K. Phenomenography: An approach to research into geography education. Journal of Geography in Higher Education. 2006, Vol. 30, Iss. 2, pp. 367-372. ISSN 0309-8265.

[83] TSENG, S. The effects of hierarchical culture on knowledge management processes. Management Research Review. 2010, Vol. 33, Iss. 8, pp. 827-839. ISSN 2040-8269.

[84] UYTERHOEVEN, H., ACKERMAN, R. and ROSENBLUM, J. Strategy and organization: Text and cases in general management. Homewood/ /llinois: Irwin, 1973. ISBN 02-5601-923-1.

[85] VON NEUMANN, J. and MORGENSTERN, O. Theory of games and economic behaviour. 2nd ed. Princeton: Princeton University Press, 1947. ISBN 06-9100-362-9. 


\section{Ekonomika a management}

[86] WHITTINGTON, R. What is strategy: And does it matter? New York: Routledge, 1993. ISBN 04-1507-385-5.

[87] WRIGHT, P., KROLL, M. and PARNELL, J. Strategic management: Concepts. 4th ed. New Jersey: Prentice-Hall, 1997. ISBN 01-3681-750-5. [88] WRIGHT, A., MURRAY, J. and GEALE, P. A phenomenographic study of what it means to supervise doctoral students. Academy of Management Learning \& Education. 2007, Vol. 6, Iss. 4, pp. 458-474. ISSN 1537-260X.
Emerson Wagner Mainardes, Ph.D.

FUCAPE Business School

Management Department and

NECE - Research Center in Business

Sciences

emerks@ubi.pt

João J. Ferreira, Ph.D.

University of Beira Interior

Management and Economics Department and

NECE - Research Center in Business

Sciences

jjmf@ubi.pt

Mario L. Raposo, Ph.D.

University of Beira Interior

Management and Economics Department and

NECE - Research Center in Business

Sciences

mraposo@ubi.pt 


\section{Abstract}

\section{STRATEGY AND STRATEGIC MANAGEMENT CONCEPTS: ARE THEY RECOGNISED BY MANAGEMENT STUDENTS?

\author{
Emerson Wagner Mainardes, João J. Ferreira, Mário L. Raposo
}

The purpose of this paper is to assess the acquired knowledge of university management students on strategy and strategic management concepts. Phenomenography was used in the analysis and a collective description was conducted. A sample of students taking management degrees at five universities was adopted. Following data analysis, a model explaining our definition of students is presented. This definition was compared with the existing literature. Our findings do not indicate a single, predominant concept but reflect a diverse set of existing concepts. We conclude that students do present difficulties when it comes to explaining their theoretical definition in real situations applied to organizations. The results contribute towards a better understanding of the universities surveyed, but cannot be generalized. Thus, we recommend future studies replicate this research project at other Higher Education Institutions and confirm the factors making up the construction of the definition of strategy from the perspective of future managers. Given that topics relating to strategy and strategic management are highly relevant to organizations today, it is of similar great importance to identifying just what future managers perceive about these issues. Our model explains the definition of strategy in the vision of young managers about to enter the market. A balance between the current schools of thought on strategy and an approach to the reality of enterprises are presented as challenges for both teachers and researchers in this field.

Key Words: Strategy, management, strategic management, concepts, management students, phenomenography.

JEL Classification: A23, L10, M00, M10.

DOI: 10.15240/tul/001/2014-1-004 